\title{
PERAN ORANGTUA DALAM KRISIS REMAJA
}

\author{
Ramot Peter \\ Character Building Development Center, BINUS University \\ Jln. Kemanggisan Ilir III No.45, Kemanggisan-Palmerah, Jakarta Barat 11480 \\ ramot.peter@binus.ac.id
}

\begin{abstract}
Crisis in youth will impact his/her personal growth, attitude, and negative sense in emotional response. The negative sense in emotional response will drive his/her action to do bad things and will disturb his/her life. To understand the negative emotional attitude when youth facing crisis, parents need to understand the crisis period, the roles, and the responsibilities of parents to help the youth overcome the crisis. The explanation is given by using qualitative data analysis and conducted concurrently with gathering data, making interpretations, and writing report. The study shows the negative emotional response of youth will impact the negative attitudes and actions. In this case, parents must guide the youth for spiritual mindsets in order to affect positive emotional attitudes and actions. The positive spiritual action will be reflected by understanding the God's Words in solving the problem, finding the way out, and overcoming the crisis. Hence, the youth crisis is not a disaster, but the reflection to reach the positive improvement.
\end{abstract}

Keywords: crisis, negative attitude, positive attitude, spiritual attitude, emotional attitude

\begin{abstract}
ABSTRAK
Krisis dalam masa remaja cenderung menimbulkan masalah bagi pertumbuhan pribadi anak dan akan berdampak pada suatu sikap emosional negatif yang akan menimbulkan krisis. Untuk memahami sikap-sikap emosional remaja ketika menghadapi krisis diperlukan pengenalan terhadap masa krisis remaja serta peranan dan tanggungjawab orangtua dalam membantu anak remajanya agar mampu mengatasi krisis. Penulis menyajikan tulisan ini dalam bentuk deskriptif kualitatif yang bertujuan untuk memberikan deskripsi secara sistematis, faktual, dan teliti dengan menggunakan data dalam bentuk kata atau gambaran. Dalam pembahasan dipaparkan bahwa sikap emosional yang bersifat negatif akan membawa perilaku remaja kepada tindakan pelarian bahkan tindakan buruk yang akan membuat hidupnya menderita. Orangtua diharapkan dapat membantu remajanya mengatasi krisis dengan membekali sikap-sikap rohani untuk mempengaruhi sikap emosional agar berdampak positif. Sikap rohani menunjukan bahwa seseorang yang mengerti firman dan kehendak Allah pasti dapat mengatasi masalah, menemukan jalan keluar dan kekuatan untuk mengatasi masa krisis. Dengan demikian, masa krisis remaja bukan bencana melainkan titik balik menuju ke arah perbaikan yang memberikan kebaikan.
\end{abstract}

Kata kunci: krisis, sikap negatif, sikap positif, sikap rohani, sikap emosional 


\section{PENDAHULUAN}

Masa remaja memang masa yang menyenangkan sekaligus masa tersulit dalam hidup seseorang. Mereka penuh mimpi, angan-angan, cita-cita, potensi, pergolakan, dan pemberontakan. Pada saat itu pula, seorang anak remaja tidak saja mengalami perubahan fisik tetapi juga psikis. Status pun berubah karena adanya perubahan sebutan dari sebagai anak-anak menjadi remaja.

Permasalahan yang sering timbul biasanya seputar hubungan mereka dengan orangtua. Banyak di antara mereka memilih jalan yang keliru meskipun dibesarkan dalam rumah tangga yang solid, baik, mengasihi, dan mendidik. Contoh dalam Alkitab 'Perumpamaan tentang anak yang hilang' (Lukas 15:11-32), seorang ayah mempunyai dua orang anak dan membesarkan mereka dengan baik namun si anak bungsu pada saat menginjak usia remaja memutuskan untuk keluar dari rumah, hidup sesuai dengan keinginan sendiri, dan lepas dari bimbingan orangtua.

Krisis remaja merupakan suatu reaksi dari dalam diri seorang remaja terhadap suatu bahaya dari luar. Suatu krisis biasanya meliputi hilangnya kemampuan untuk mengatasi masalah selama sementara waktu. Jika ia mampu mengatasi masalah itu secara efektif, ia dapat kembali berfungsi seperti keadaan sebelum krisis. Dengan kata lain, krisis dapat menjadi titik balik; bisa menuju ke arah perbaikan atau kehancuran tanpa penyelesaian. Oleh karena itu diperlukan suatu sikap ketika menghadapi krisis walaupun kecenderungan bereaksi negatif. Jika kita melakukan reaksi negatif, kehancuran bagian hidup kita. Sebaliknya jika kita melakukan reaksi positif, maka dengan adanya krisis itu akan ada dampak-dampak positif untuk kebaikan dalam hidup kita sebagai titik balik. Selain sikap positif remaja, diperlukan juga peran orangtua untuk membantu anak remajanya membangun sikap dengan dukungan secara rohani.

Untuk mendukung pemahaman tentang sikap-sikap emosional remaja ketika menghadapi krisis, artikel ini membahas pengenalan terhadap masa krisis remaja; serta, peranan dan tanggung jawab orangtua dalam membantu anak remajanya agar mampu mengatasi masa krisis anak remajanya. Diharapkan dengan pembahasan hal-hal tersebut, seorang remaja mampu menghadapi dan mengatasi krisis dengan pendekatan secara rohani dari orangtua. Adapun yang menjadi tujuan dari artikel ini adalah untuk membangun wawasan orangtua untuk membantu anak remajanya dalam menghadapi krisis masa remaja dengan sikap-sikap positif dan didukung dengan sikap rohani sehingga menjadikan krisis sebuah pengalaman yang positif.

\section{METODE}

Penelitian ini merupakan penelitian deskriptif kualitatif yang bertujuan untuk mendeskripsikan fakta-fakta atau pemahaman yang jelas tentang suatu peristiwa, kondisi atau situasi. Metode penelitian deskriptif kualitatif berusaha untuk memberikan deskripsi secara sistematis, faktual, dan teliti dengan menggunakan data dalam bentuk kata atau gambaran. Fokusnya adalah penggambaran secara menyeluruh tentang bentuk, fungsi, makna dan ungkapan hasil pemikiran. Creswell (2009:184) menyatakan "that qualitative data analysis is conducted concurrently with gathering data, making interpretations, and writing reports." Dengan kata lain, penelitian ini disebut penelitian kualitatif karena merupakan penelitian yang tidak mengadakan perhitungan angka. Dalam tulisan ini penulis menggunakan metode literatur atau kepustakaan, yaitu dengan jalan membaca buku dan mencari informasi dari media massa dan media elektronik, serta menggunakan pendapat para ahli yang terdapat dalam buku atau sumber informasi lainnya sebagai bahan dasar teori yang ada hubungannya dengan masalah penelitian. 


\section{PEMBAHASAN}

Seiring dengan cepatnya perkembangan teknologi, anak remaja tumbuh lebih cepat dan ingin bebas lebih awal. Banyak orangtua yang merasa sulit mengikuti perubahan-perubahan drastis yang dialami anak remaja mereka dan sebagai akibatnya terjadilah pertentangan. Tadinya si anak masih dalam pelukan orangtua, diantar ke sekolah, bermain bersama di rumah, membantu urusan rumah, dan seterusnya lalu tiba-tiba berubah. Dia mulai berani membantah, melawan, dan melanggar peraturan dari orangtua, serta tidak komunikatif lagi terhadap orangtua. Hal ini sebagai pertanda masa remaja sudah tiba, situasi tidak lagi dapat dikendalikan oleh orangtua. Di satu sisi orangtua memperketat kontrol, di sisi lain remaja meningkatkan pula perlawanan mereka untuk mendapat kebebasan. Oleh karena itu, orangtua harus mengenal masa krisis anak remaja dan bertanggung jawab membantu anak remaja secara rohani mengatasi masa-masa krisis tersebut.

\section{Mengenal Masa Krisis Remaja}

Pendapat umum mengatakan bahwa masa remaja merupakan masa peralihan antara tahap kanak-kanak dengan tahap dewasa. Wright (2009) mengatakan bahwa masa remaja merupakan suatu masa krisis terus-menerus dengan diselingi beberapa masa reda dengan pengalaman yang menegangkan, stres, badai bahkan tekanan sosial memuncak. Mereka beranjak dari ketergantungan kepada orangtua menuju kemandirian, otonomi, dan kematangan. Perubahan ini tentunya setiap budaya akan memiliki ciri tersendiri, misalnya mengenai batasan umur. Di Indonesia, meskipun belum ada kesepakatan tentang hal ini, kategori remaja umumnya di Indonesia berkisar usia dua belas tahun hingga dua puluh tahun.

Ada dua ciri-ciri yang menonjol ketika seorang anak memasuki usia remaja (Surbakti, 2008), yaitu perubahan fisik dan psikis. Perubahan fisik bagi laki-laki ditandai dengan perubahan otot, suara menjadi besar, tumbuh jakun, tumbuh kumis; sedangkan pada perempuan ditandai dengan tumbuh payudara, mengalami menstruasi, tubuh makin seksi. Sementara itu perubahan psikis sulit diamati secara kasat mata. Berkembangnya intelektual, emosional, minat, dan sikap dapat dipandang sebagai ciri-ciri perkembangan psikis. Bisa saja pertumbuhan seorang anak remaja secara fisik tidak selalu diikuti secara psikis, begitu pula sebaliknya.

Perubahan secara psikis berdampak besar terhadap prilaku secara emosional. Oleh karena itu, masa remaja merupakan masa yang rentan terhadap godaan, rasa keingintahuan akan segala hal sehingga mereka gampang terjerumus dengan hal-hal negatif, misalnya: penggunaan obat-obat terlarang, keterikatan misalnya dengan playstation, game internet, chatting, video porno, dan akses situs porno. Lingkungan tempat mereka berada pun sangat berpengaruh besar. Tahap-tahap keterlibatan narkoba atau obat-obat terlarang dimulai dari coba-coba, pertemanan, rekreasi ataupun pesta bersama, mulai membeli pakai sendiri lalu kecanduan. Rapuhnya pernikahan, sistem keluarga yang bermasalah, dan pengawasan orang tua berkurang dapat menjadi pemicu utama kecenderungan timbulnya gejala-gejala psikis tersebut hingga pelanggaran hukum.

Sikap-sikap yang diambil oleh remaja yang disebutkan di atas merupakan suatu pelarian (Peter, 2014:883). Pelarian ini merupakan sikap negatif yang bisa bersifat sementara dan bisa juga berulang yang akan memperparah kondisi krisis remaja. Hasil akhir dari sikap emosional yang negatif cenderung akan membawa kehidupan seseorang tanpa arah yang baik. Masalah akan makin sulit bahkan memperburuk kondisi secara fisik maupun psikis sehigga sering terjadi pemberontakan terhadap orangtua.

Karena pengaruh tersebut sangat solid, sering timbul kurang bahkan hilangnya wibawa orangtua di hadapan mereka sehingga menimbulkan pertentangan. Pertentangan yang sering terjadi 
adalah pertentangan antara orangtua dan anak remaja dalam wilayah: pertemanan, cara berhias, kencan, tugas-tugas rumah, uang saku, penggunaan kendaraan, sekolah dan pekerjaan rumah, disiplin, dan lain-lain. Hal ini sebagian kecil dari tumpukan masalah yang timbul sehingga muncullah rintangan komunikasi. Orangtua merasa sulit berbicara dengan anak-anak mereka. Mereka menunda penjelasan tentang perubahan-perubahan mental dan jasmani yang menentukan, terutama dalam wilayah seks dan reproduksi. Orangtua memperketat kontrol, remaja meningkatkan pula perlawanan mereka untuk mendapatkan kebebasan. Jurang melebar lalu mulailah pertentangan.

\section{Ilustrasi:}

Sebagai contoh, ada satu keluarga hidup di kota kecil memiliki dua anak remaja wanita yang ingin sekolah di kota besar. Kedua anak remaja tersebut masih duduk di bangku SMU dan sangat gaul dengan teman sebayanya terlebih dari keluarga yang orangtuanya kecukupan. Sejak memasuki usia remaja, sikap dan tingkah laku mereka mulai berubah. Misalnya, mereka tidak banyak bicara lagi dengan orangtua tetapi bisa berjam-jam bercakap-cakap di telepon atau chatting dengan temannya. Mereka lebih sering diam di kamarnya dan tidak banyak bicara lagi dengan orangtua. Ayah mereka sangat sibuk dengan pekerjaannya sebagai pengusaha sehingga sulit untuk dapat diajak bicara oleh kedua anak mereka juga oleh istri. Istri karena cenderung menghadapi sendiri segala tingkah laku anak sehari-hari dan banyak tahu perkembangan anak lalu merasakan suatu ketegangan dalam menghadapi kedua anak remajanya terlebih setelah mendengarkan rencana anak remajanya tersebut. Istri atau ibu merasa terlalu cepat jika anak-anak remaja mereka ingin meninggalkan orangtua. Dia masih menganggap mereka belum siap untuk mandiri. Mereka masih tampak kekanak-kanakan, mengatur kamar sendiri saja belum bisa, waktu makan dan tidur pun harus diperingatkan, belum bisa mengontrol pemakaian uang, yang jelas semua masih perlu kontrol maksimal dari seorang ibu. Karena pergaulan dan banyak melihat contoh-contoh di luar rumah, kedua anak remaja tersebut sudah mulai mencemaskan. Mereka sudah makin sulit diawasi dan tidak menerima nasihat, bahkan tidak suka ketika ditanya dari mana, mau ke mana, dan dengan siapa mereka pergi.

Dari ilustrasi di atas perubahan status seorang remaja menganggap dirinya sudah dewasa, mandiri, berani dan punya energi yang hebat. Jika tidak mendapat pengarahan yang baik, masa transisi anak remaja akan mengalami krisis karena mereka masih mudah terombang-ambing atau labil dan suka mencoba hal-hal baru tanpa memikirkan akibat buruknya, misalnya: merokok, minuman keras, narkoba bahkan seks bebas. Orangtua dituntut untuk mengenal dan memahami bahwa memang masa remaja itu penuh tantangan yang akan dihadapi. Masa remaja menghadirkan begitu banyak tantangan karena banyaknya perubahan yang dihadapi bahkan bukan hanya secara fisik dan psikis tetapi juga secara sosial. Inilah tantangan terbesar bagi remaja karena mereka butuh untuk menemukan tempat mereka dalam masyarakat.

Kombinasi kehidupan remaja dalam masyarakat, orangtua, dan teman sebaya akan mempengaruhi prilaku sosial. Sebagai konsekuensinya, akan muncul ambivalensi yang mencolok berkenaan dengan isu ketergantungan dan kemandirian dan dalam hubungannya dengan mengekspresikan perubahan sikap dan prilaku, sementara pada saat bersamaan mempertahankan hubungan sosial.

Kebanyakan orangtua tidak mengetahui apakah harapan mereka terhadap anak remajanya itu normal atau realistis. Bahkan banyak orangtua khawatir dan merasa tertekan menghadapi prilaku mereka. Hipotesis Steinberg menyatakan bahwa ketika anak-anak mencapai pubertas, kombinasi dari tahap perkembangan remaja dan perilaku serta emosi orangtua akan menghasilkan perubahan besar pada orangtua, yaitu meningginya tingkat stres (Geldard \& Geldard, 2011:22). Perubahan-perubahan ini diyakini Steinberg sering kali mengakibatkan terlepasnya ikatan orangtua dengan anak-anak remaja mereka (Geldard \& Geldard, 2011). 
Keadaan tersebut menyebabkan banyak orangtua merasa kecewa dan akhirnya mengabaikan perhatian bahkan curahan kasih sayang. Gagalnya fungsi keluarga ini semakin mendorong kebanyakan remaja pada usia sekitar 14 tahun mulai menjauhkan diri dari orangtua. Padahal benang merah keberhasilan mereka adalah menjaga hubungan yang positif dengan orangtua mereka. Akan tetapi, tidaklah mudah bagi orangtua untuk menyesuaikan diri dengan anak remaja yang sedang mengalami gejolak. Oleh karena itu sebagai orangtua sangat diharapkan untuk menunjukkan peran dan tanggung jawabnya untuk membimbing anak remajanya agar tidak menyimpang dari jalan kebenaran.

\section{Peran dan Tanggung Jawab Orangtua kepada Anak Remaja}

Pembentukan jati diri merupakan suatu proses berkesinambungan melampaui masa remaja. Identitas atau jati diri adalah gambar atau pemahaman tentang siapakah kita ini. Pada masa kanakkanak, kita sangat tergantung pada orangtua sedangkan pada masa remaja dapat dikatakan sudah dapat hidup secara mandiri, kecuali dalam aspek keuangan. Pada saat itu kita mulai bisa melihat gambar atau pemahaman tentang jatidiri dan semakin menyadari keinginan-keinginan dalam diri kita.

Pada masa remaja, kehidupan sosial meluas sehingga peran orangtua mulai menciut. Orangtua yang tadinya merupakan pusat kehidupan sosial anak sekarang tersisihkan dan digantikan dengan teman-teman sebayanya. Sebelumnya anak selalu bertanya bila hendak melakukan sesuatu. Sekarang anak mulai menunjukan keengganannya meminta pendapat apalagi izin orangtua. Jika dahulu anak selalu menceritakan semua peristiwa yang dialaminya, sekarang anak mulai menyimpan rahasia. Acapkali orangtua menafsirkan perilaku anak ini secara negatif, seolah anak merahasiakan hal yang buruk.

Kesalahan orangtua dalam merespons sikap remaja terkadang mengarah kepada pengekangan. Tindakan ini akan membuat potensi mereka tumpul, tidak berkembang, dan banyak di antara mereka menjadi frustasi. Pengekangan tentu akan merugikan perkembangan seorang remaja yang akan mengakibatkan: tidak mandiri dan tidak berani berkompetisi; tidak berani mengambil keputusan; tidak mampu melakukan lompatan besar dalam studi; tidak berani memulai sesuatu yang baru dan tidak bertanggung jawab; lebih senang dipimpin daripada memimpin; sulit bersosialisasi (inferior). Beberapa hal tersebut merupakan dampak akibat pengekangan yang berlebihan (Surbakti, 2008). Orangtua perlu arif dan bijaksana dan perlu memberikan toleransi kepada anak remajanya.

Adakalanya anak menyimpan hal yang buruk, namun biasanya mereka merasa tidak perlu lagi untuk menceritakan setiap peristiwa yang dialaminya kepada orangtua. Hal inilah yang disebut dengan gap antara orangtua dan anak-anak. Menurut Susabda (2011), gap atau jurang pemisah terjadi karena kekurangtahuan orangtua tentang prinsip-prinsip pendidikan anak-anak yang berakibat renggannya hubungan antara orangtua dan anak-anak. Anak remaja cenderung mengungkapkan pengalamannya dengan teman sebaya bahkan akan lebih bersemangat dalam penyampaian. Teman sebaya sudah pasti lebih memiliki kesamaan dengannya karena hidup dalam dunia yang sama. Di sinilah dituntut kesediaan orangtua untuk mempelajari dunia anak remaja agar mereka dapat melihat bahwa orangtuanya sungguh memahami pikirannya.

Di sisi lain perlu dipahami secara benar bahwa anak-anak adalah produk langsung dari orangtua dan bukan produk langsung dari pendidikan atau sekolah ataupun gereja. Tanggung jawab untuk membesarkan anak pada pundak orangtua dan dimulai dari keluarga atau rumah tangga bukan pada pendidik maupun rohaniawan. Oleh karena itu perlu dimaknai keluarga sebagai tempat seseorang bertumbuh dan berkembang menjadi individu yang berkepribadian dan berkarakter (Surbakti, 2008:251). Kehidupan keluarga dan cara orangtua membesarkan anak dalam keluarga akan berdampak langsung pada perkembangan anak.

Sikap orangtua sangat menentukan pembentukan konsep dari anak tentang dirinya, tentang hidup dan terlebih tentang Tuhan. Dalam contoh kasus kedua anak remaja yang ingin melanjutkan 
pendidikan di luar kota bahkan kota besar telah menimbulkan keresahan bagi seorang ibu. Yang perlu menjalani konseling untuk masalah ini adalah kedua orangtua (suami dan istri) serta anak-anaknya. Yang datang pada konselor memang hanya ibu namun akan lebih efektif jika konseling diarahkan kepada ketiga aktor utama dalam rumah tangga yaitu ayah, ibu, dan anak dalam hubungannya dengan Tuhan.

Sistem yang sudah terbentuk dalam keluarga memang sulit diubah. Dalam kasus ini, istri terlihat mendidik sendiri sedangkan suami kurang terlibat dan tidak mendapat tempat. Hal ini tampak pada saat istri ragu-ragu dan khawatir suami kurang peduli. Ketika istri gelisah seperti ini, rasanya semua yang kurang tampak yaitu tanggung jawab dan pergaulan terhadap anggota keluarga bahkan dengan Tuhan. Sedangkan hal yang tampak adalah kasih sayang istri terhadap kedua anak remajanya secara berlebihan. Hal-hal sekecil apapun menjadi perhatian istri, bahkan mengambil semua tanggung jawab. Tanpa disadari, istri sudah memanjakan mereka berdua secara berlebihan. Ketika tiba saatnya kedua anak remajanya menunjukkan kemandirian, istri merasa tertolak bahkan sering mendapat respons yang tidak menyenangkan.

Konsele utama dalam kasus ini adalah peran orangtua, khususnya ayah dalam mendidik anak remajanya. Meskipun semuanya membicarakan tentang tugas mendidik anak, ada keunikan masingmasing dalam konteks sumbangsih ayah dan ibu dalam mendidik anak. Salah satu tugas utama ayah kristiani: "Kamu harus mengajarkannya kepada anak-anakmu dengan membicarakannya, apabila engkau duduk di rumahmu dan apabila engkau sedang dalam perjalanan, apabila engkau berbaring dan apabila engkau bangun," (Ulangan 11:19). Tuhan menghendaki agar seorang ayah dapat mengajarkan perintah Tuhan dengan membicarakannya secara tepat walau sukar dan pada waktu yang tepat agar dapat dicerna oleh anak. Dampaknya akan terlihat seperti tertulis dalam firmanNya: "Segala sesuatu yang kamu kehendaki supaya orang perbuat kepadamu, perbuatlah demikian juga kepada mereka. Itulah isi seluruh Hukum Taurat dan kitab para nabi,” (Matius 7:12). Berbahagialah orang yang mampu menerapkan Firman Tuhan, apabila seseorang memperlakukan orang lain sama seperti ia ingin diperlakukan, ia sudah memiliki emas yang tak ternilai. Sebagai ayah tentu rindu agar anakanaknya mempunyai emas yang tak ternilai itu dan Tuhan Yesus telah menyediakan sarananya.

Melalui contoh kasus yang sudah dibicarakan, terdapat empat hal yang berfaedah untuk seorang ayah lakukan. Pertama, menyediakan waktu untuk bersama. Kerinduan menjadi ayah yang baik adalah penting namun harus diwujudkan dalam bentuk waktu yang diberikan bagi anak. Tanpa memberi waktu tidak akan ada kesempatan untuk mengajarkan dan membicarakan pedoman hidup yang berasal dari Firman Tuhan. Kedua, mengenali kelemahan anak. Keterbukaan diperlukan untuk menerima kenyataan bahwa anak bukan saja tidak sempurna, namun akibat dosa, ia pun berpotensi merugikan orang lain. Adakalanya sulit untuk mengakui kelemahan anak karena kelemahannya sedikit banyak merefleksikan kekurangan orangtua. Ketiga, melakukan pendekatan kasih bukan konfrontasi. Kadang perlu memperhadapkan anak dengan perbuatannya secara tegas bahkan sesekali perlu menghukumnya. Menegur anak dengan kasih; makin keras teguran kepada mereka makin bersikeras ia menyangkalnya. Sebaliknya, dengan lemah lembut menegurnya, ia akan luluh dan bersedia menerima perkataan. Keempat, mengenal Firman Tuhan. Tanpa pengenalan akan Firman Tuhan, seorang ayah akan gagal mendidik anaknya seturut Firman Tuhan.

Selain empat hal tersebut, ada beberapa hal yang dapat menjadi pertimbangan ataupun anjuran kepada orangtua (Surbakti, 2008:293) untuk mengatasi konflik dengan anak-anak remajanya. Pertama, bertindak sebagai teman diskusi yang menyenangkan. Kedua, menghindari sikap menyalahkan dan menghakimi. Ketiga, mengarahkan potensi dan energi mereka yang besar pada hal-hal yang positif dan bermanfaat bagi masa depannya. Keempat, jangan melecehkan kondisi psikologis mereka yang labil. Kelima, menghindari hukuman yang dapat membuat perasaan mereka terluka. Keenam, menjelaskan setiap fase perkembangan mereka yang dapat menyebabkan perubahan kondisi psikologis mereka. 
Selanjutnya tanggung jawab remaja dalam mengatasi masalahnya dalam keluarga. Mereka tidak bisa menimpakan semua kesalahan pada orangtua sebab orangtua adalah manusia biasa yang tidak sempurna. Menerima orangtua sebagaimana adanya, acapkali mengambil tindakan yang tidak disukai anak remaja karena ketakutan orangtua akan terjadi musibah, salah langkah, salah bertindak yang akan berakibat fatal. Firman Tuhan dalam Amsal 23:22-25 merupakan nasihat kepada anak remaja. Mencari kebenaran meski orangtua mungkin kurang benar, tetapi anak bertanggung jawab untuk hidup benar sesuai dengan yang ditunjukkan Tuhan. Jika anak hidup dalam kebenaran Tuhan, yang akan bersorak sorai adalah orangtua. Tetapi jika anak jatuh dalam dosa karena kesalahan sendiri jangan mempersalahkan orangtua. Kelak anak akan mempertanggungjawabkannya di hadapan Tuhan. Jika anak hidup dalam kebenaran Tuhan, yang akan bersorak sorai adalah orangtua.

Seorang anak harus mengerti bahwa dengan tidak taat kepada orangtua berarti melawan perintah Allah. Adams (2006:135) mengatakan apabila mereka melanggar peraturan di rumah, apabila mereka tidak menghormati orang tua, pada dasarnya mereka memberontak kepada Allah yang memerintah seperti tertulis dalam Efesus 6 ayat 1. Jadi apabila anak menaati orangtua, berarti mereka memuliakan Allah demi terciptanya kedamaian dan ketertiban dalam rumah tangga.

\section{SIMPULAN}

Dalam menjalani masa yang dikenal dengan masa transisi, remaja akan mengalami banyak gejolak yang akan menjadi permasalahan yang tidak berdiri sendiri. Banyak faktor pemicu baik secara internal maupun eksternal yang membawa kekhawatiran yang berlebihan. Hal ini menyebabkan anak remaja menjadi mudah cemas, penakut, terkekang, dan bergantung kepada orangtua. Akibatnya, aktivitas terganggu dan kreativitas terbelenggu. Sebaliknya, jika orangtua memberikan kebebasan yang berlebihan juga akan menghancurkan hidup anak remaja mereka. Bagaimanapun juga, perlu diketahui bahwa tidak ada seorang remaja di muka bumi ini yang kebal terhadap masa krisis tersebut. Demikian juga, tidak ada remaja yang akan mengalami suasana krisis selamanya.

Oleh karena itu, kewajiban orangtua merupakan hal yang utama. Orangtua harus berusaha selalu memberikan teladan hidup yang baik sebagai refleksi atas iman. Masa krisis anak remaja tidak lepas dari campur tangan Tuhan. Dia mengizinkan krisis hadir dalam hidup remaja karena Dia tahu bahwa setiap masalah dan cobaan akan berguna untuk kebaikan. Remaja dapat bertumbuh dalam berbagai segi kehidupan secara rohani, mental, psikologis, dan emosional.

Berbagai krisis akan membuat remaja berkembang karena menyediakan begitu banyak pula kesempatan untuk memperbaiki cara hidup. Maka dari itu, krisis masa remaja tidak perlu direspons dengan sikap negatif yang justru akan makin menjerumuskan mereka atau menimbulkan krisis-krisis lainnya. Sebaliknya, setiap krisis disikapi dengan sikap positif dan rohani agar membuahkan kebaikan dalam hidup. 


\section{DAFTAR PUSTAKA}

Adams, J. E. (2006). Competent to Counsel: Anda Pun Boleh Membimbing (Terjemahan). Malang: Gandum Mas.

Creswell, J. W. (2009). Research Design: Qualitative, Quantitative, and Mixed Methods Approaches. California: Sage Publications.

Geldard, K., \& Geldard, D. (2011). Konseling Remaja: Pendekatan Proaktif untuk Anak Muda (Terjemahan). Yogyakarta: Pustaka Pelajar.

Peter, R. (2014). Sikap emosional ketika menghadapi krisis. Humaniora, 5(2), 881-888.

Surbakti, E. B. (2008). Konseling Praktis: Mengatasi Berbagai Masalah. Bandung: Kalam Hidup.

Susabda, Y. B. (2011). Pastoral Konseling (Jilid 2). Malang: Gandum Mas.

Wright, N. H. (2009). Konseling Krisis: Membantu Orang Dalam Krisis dan Stress (Terjemahan). Malang: Gandum Mas. 